\title{
MANAJEMEN PENGELOLAAN LAHAN KRITIS \\ PADA DAS BRANTAS HULU BERBASIS MASYARAKAT \\ (Pilot Project Desa Bulukerto, Kota Batu)
}

\author{
Sri Harini, Suyono, Elok Mutiara
}

Dosen UIN Maulana Malik Ibrahim Malang

\begin{abstract}
Management of critical farm base on society represents a new approach to all researcher of environment this time. In management of farm base on this society, society invited directly start from planning, formulation of policy, its benefit collection and execution. With this direct participation enable society can calculate directly impact economical and environment (natural resources conservation), because this two aspect represent two inseparable aspect in doing study management of SDA, because having very important role in supporting efficacy of program of Participatory Action Research (PAR). Pursuant to result of discussion and dig of information of society hence a success main problem identified with society member pursuant to antecedent study (research preliminary) which have been conducted by researcher related to program management of critical farm base on society taken as focus in enable ness is critical condition survey of forest farm, socialization of UU No. 32 year 2009 about management and protection of environment, socialization and training of system of terasiring pattern and plant real correct at farm with high inclination (> 450) having economic value and with vision of environment. Marginally cycle of PAR conducted at this enable ness program is to use technical method, mapping, transect, diagram of Venn, change schema and of livelihood analysis. By using this approach is expected by society have awareness in managing and exploiting environment real correctly. Besides society can direct control to all impact and policy of the policy because related to source of their residence environment and living.
\end{abstract}

Keywords : Erosion, Critical Farm, Research Preliminary, Participatory Action Research, Mapping, Transect, Diagram of Venn, Change Schema, Analysis livelihood

PENDAHULUAN

Era reformasi tahun 1998

berdampak serius terhadap lingkungan

di Sub DAS Brantas Hulu. Perubahan

sistem pengelolaan sumber daya alam

(SDA) dari pusat menjadi otonomi

daerah membawa dampak pada

perubahan perilaku masyarakat.
Kepemilikan lahan yang bersifat common properties mulai dijadikan alasan individu untuk mengeksploitasi lahan secara bebas tanpa memperhatikan dampak kerusakan lingkungan, nilai ekonomi lahan jangka panjang, kondisi dan tata guna lahan yang benar. Masyarakat merasa 
mempunyai hak penuh dan pemilik eksklusif atas lahan tersebut. Hal inilah yang menimbulkan konflik berkepanjangan antara pemerintah dan masyarakat.

Selain itu, akibat perubahan pengelolaan ini, hutan-hutan di daerah sekitar Sub DAS Brantas Hulu banyak yang gundul dan mengalami alih fungsi menjadi lahan pertanian, perumahan dan lainnya. Secara mendasar ada beberapa perubahan alih fungsi hutan yaitu: mulai turunnya jumlah hutan di lokasi ini, berkurangnya sumber mata air, tererosinya lapisan tanah yang subur, timbulnya longsor, pendangkalan sungai dan pada akhirnya membawa dampak perubahan ke arah lahan kritis. Kekritisan lahan di Sub DAS Brantas Hulu ini sebagian besar terjadi di wilayah yang memiliki lereng curam dengan kemiringan berkisar 40-60\% hingga $>60 \%$ yang berada di pegunungan Anjasmoro, Arjuno, Panderman dan sebagian kecil Gunung Wukir.

Berbagai cara untuk menangani lahan kritis telah dilakukan oleh pemerintah, antara lain melalui program reboisasi dan penghijauan. Keberhasilan fisik reboisasi selama Pelita IV baru sekitar 68\%, sedangkan penghijauan hanya 21\%. Hal ini mungkin disebabkan karena kurang tepatnya teknologi yang digunakan, atau kondisi lahan belum dipelajari dengan cermat, atau karena teknologi tidak diterapkan sepenuhnya. Ditinjau dari segi pelestarian lingkungan dan efisiensi penggunaan dana dalam program ekstensifikasi maka pemanfaatan lahan kritis dengan perbaikan produktivitas mungkin lebih baik daripada membuka hutan. Produktivitas beberapa jenis lahan kritis misalnya lahan alang-alang relatif lebih mudah diperbaiki untuk budidaya tanaman pangan (Manwan, 1993).

Manajemen pengelolaan lahan kritis berbasis masyarakat merupakan sebuah pendekatan baru bagi para peneliti lingkungan hidup. Dalam manajemen pengelolaan lahan berbasis masyarakat ini, masyarakat diajak secara langsung mulai dari perencanaan, perumusan kebijakan, pelaksanaan dan pemungutan manfaatnya. Pendekatan ini memungkinkan masyarakat dapat menghitung secara langsung dampak secara ekonomi dan lingkungan hidup (konservasi SDA). Dua aspek tersebut tidak dapat dipisahkan dalam melakukan kajian pengelolaan SDA dalam rangka mendukung keberhasilan 
program PAR ini. Dengan menggunakan pendekatan ini diharapkan masyarakat memiliki kesadaran dalam mengelola dan memanfaatkan lingkungan secara benar. Selain itu masyarakat dapat melakukan kontrol langsung terhadap segala kebijakan dan dampak dari kebijakan tersebut berkaitan dengan sumber mata pencaharian dan lingkungan tempat tinggal mereka.

\section{KAJIAN PUSTAKA}

\section{Pemberdayaan Masyarakat}

Istilah pemberdayaan

(empowerment) bukanlah istilah baru. Ini muncul hampir bersamaan dengan adanya kesadaran akan perlunya partisipasi masyarakat dalam pembangunan. Diasumsikan bahwa kegiatan pembangunan itu mestinya mampu merangsang proses pemandirian masyarakat (self sustaining process). Ada hipotesis bahwa tanpa partisipasi masyarakat niscaya tidak akan diperoleh kemajuan yang berarti dalam proses pemandirian tersebut. Adanya gagasan bahwa partisipasi masyarakat itu seyogyanya merefleksikan pemandirian bukanlah tanpa alasan. Diasumsikan bahwa tanpa adanya pemandirian maka suatu bentuk partisipasi masyarakat itu hanyalah proses mobilisasi belaka.

Definisi lain mengacu pada sebuah gerakan dengan semangat pembebasan masyarakat dari belenggu ideologi dan relasi kekuatan yang menghambat manusia dalam mencapai perkembangan harkat dan martabatnya. Sebuah proses dimana kelompok sosial kelas bawah mengontrol ilmu pengetahuan dan membangun kekuatan poitik melalui pendidikan orang dewasa, penelitian kritis dan tindakan sosial-politik. Proses masyarakat membangun kesadaran diri melalui dialog dan refleksi kritis;

1. Kurt Lewin (1947) dikenal sebagai pencetus terminology "Action Research". Action Research adalah proses spiral yang meliputi (1) perencanaan tindakan yang melibatkan investigasi yang cermat; (2) pelaksanaan tindakan; penemuan fakta-fakta tentang hasil dari tindakan, dan (4) penemuan makna baru dari pengalaman sosial.

2. Corey (1953) mengartikan Action Research adalah proses dimana kelompok sosial berusaha melakukan studi masalah mereka secara ilmiyah dalam rangka mengarahkan, memperbaiki dan mengevaluasi keputusan dan 
tindakan mereka.

3. Hopkins (1985) berpendapat bahwa Action Research dimaksudkan untuk mengkontribusikan baik pada masalah praktis pemecahan masalah maupun pada tujuan ilmu sosial itu sendiri dengan mengkolaborasikan didalamnya yang dapat diterima oleh kerangka kerja etik.

4. Peter Park (1993) mengartikan Action Research sebagai cara penguatan rakyat melalui penyadaran diri untuk melakukan tindakan yang efektif menuju perbaikan kondisi kehidupan mereka.

Dalam tataran konseptual, istilah pemberdayaan itu nampaknya tidak ada persoalan. Ia berkait erat dengan proses transformasi sosial, ekonomi, politik dan budaya. Pemberdayaan ialah proses penumbuhan kekuasaan dan kemampuan diri dari kelompok masyarakat yang miskin/lemah, terpinggirkan dan tertindas. Melalui proses pemberdayaan diasumsikan bahwa kelompok masyarakat dari strata sosial terendah sekali pun bisa saja terangkat dan muncul menjadi bagian dari lapisan masyarakat menengah dan atas. Ini akan terjadi bila mereka bukan saja diberi kesempatan akan tetapi mendapatkan bantuan atau terfasilitasi pihak lain yang memiliki komitmen untuk itu. Kelompok miskin di pedesaan misalnya, niscaya tidak akan mampu melakukan proses pemberdayaan sendiri tanpa bantuan atau fasilitasi pihak lain. Harus ada sekelompok orang atau suatu institusi yang bertindak sebagai pemicu keberdayaan (enabler) bagi mereka.

Pemberdayaan Masyarakat dengan demikian sama sekali berbeda dengan apa yang biasa disebut dengan pendekatan kariatif (memberi bantuan dengan dasar belas kasihan) dan pengembangan masyarakat (community development) yang biasanya berisi pembinaan, penyuluhan, bantuan teknis dan manajemen serta mendorong keswadayaan. Dua pendekatan ini biasanya berupa intervensi dari orang luar yang mengambil inisiatif, memutuskan dan melakukan sesuai pikirannya sendiri. Masyarakat 'diikutkan' sebagai obyek pembangunan. Pihak luar berperan sebagai pembina, penyuluh, pembimbing dan pemberi bantuan. Pemberdayaan adalah proses dari, oleh dan untuk masyarakat, di mana masyarakat di samping difasilitasi dalam mengambil keputusan dan 
berinisiatif sendiri agar mereka lebih mandiri dalam pengembangan dan peningkatan taraf hidupnya. Masyarakat adalah subyek pembangunan. Pihak luar berperan sebagai fasilitator.

Memahami konsep pemberdayaan masyarakat secara mendasar berarti menempatkan rakyat beserta institusi-institusinya sebagai kekuatan dasar bagi pembangunan ekonomi, politik, sosial, dan budaya. Pemberdayaan masyarakat sebenarnya bukan saja berupa tuntutan atas pembagian secara adil aset ekonomi tetapi juga merupakan keniscayaan ideologis dengan semangat meruntuhkan dominasi-dominasi birokrasi dalam mengatur dan menentukan berbagai bidang kehidupan rakyat.

Pemberdayaan masyarakat dimasa sekarang mempunyai kendala yang sangat kompleks karena "rezim pertumbuhan" ala orde baru telah banyak menyisakan rancang bangun yang tidak ramah terhadap rakyat banyak disamping menimbulkan kerusakan yang dahsyat terhadap sumber daya alam. Kesukaran lain yang juga akan dihadapi adalah menyangkut kesiapan teknis dari berbagai pihak terutama birokrasi/pemerintah dan legislatif karena mau atau tidak mau gagasan pemberdayaan rakyat harus dibarengi dengan perubahan kultural ditingkat perilaku politik terutama birokrasi dan legislatif (Adi Sasono, 1998). Berangkat dari pengertian diatas, dapatlah dimengerti bahwa hakikat pemberdayaan adalah upaya melepaskan berbagai bentuk dominasi budaya, tekanan politik, eksploitasi ekonomi, yang menghalangi upaya masyarakat menentukan diri mereka sendiri serta upaya-upaya mengatasinya. Kindervatter memberikan batasan pemberdayaan sebagai peningkatan pemahaman manusia untuk meningkatkan kedudukannya di masyarakat. Peningkatan kedudukan itu meliputi kondisi-kondisi sebagai berikut:

1) Akses, memiliki peluang yang cukup besar untuk mendapatkan sumbersumber daya dan sumber dana.

2) Daya pengungkit, meningkat dalam hal daya tawar kolektifnya.

3) Pilihan-pilihan, mampu dan memiliki peluang terhadap berbagai plihan.

4) Status, meningkatkan citra diri, kepuasan diri, dan memiliki perasaan yang positif atas identitas budayanya.

5) Kemampuan refleksi kritis, 
menggunakan pengalaman untuk mengukur potensi keunggulannya atas berbagai peluang pilihan-pilihan dalam pemecahan masalah.

6) Legitimasi, ada pertimbangan ahli yang menjadi justifikasi atau yang membenarkan terhadap alasan-alasan rasional atas kebutuhan-kebutuhan masyarakat.

7) Disiplin, menetapkan sendiri standar mutu untuk pekerjaan yang dilakukan untuk orang lain

8) Persepsi kreatif, sebuah pandangan yang lebih positif dan inovatif terhadap hubungan dirinya dengan lingkungannya.

\section{Strategi Pemberdayaan Masyarakat}

Uraian di atas memberikan penjelasan bahwa peristiwa pembangunan tidaklah cukup dipahami sebagai peristiwa ekonomi an sich. Setiap peristiwa pembangunan selalu memiliki dimensi ekonomi, politik, dan budaya. Oleh karena itu dapat dipahami mengapa berbagai upaya yang hanya berdimensi ekonomi selalu menemui kegagalan dan tidak membawa perubahan yang cukup berarti. Pemberdayaan masyarakat membutuhkan komitmen yang kuat dari pemerintah, legislatif, para pelaku ekonomi, rakyat, lembaga-lembaga pendidikan serta organisasi-organisasi non pemerintah. Cara kerja yang langsung berhubungan dengan masyarakat di lapis bawah memberikan peluang yang luas untuk menggerakkan dan melancarkan proses belajar masyarakat dalam membangun kehidupannya melalui kerja-kerja konkrit dan melalui uji coba-uji coba dalam skala mikro, kecil dan menengah. Dalam kaitan ini fasilitator pemberdayaan masyarakat memiliki peran yang sangat strategis. Fasilitator bukanlah pekerja an sich yang bekerja dengan model "tukang" tetapi mereka adalah aktivis yang bekerja penuh komitmen dan kreativitas serta memiliki semangat tinggi membangun masyarakat belajar membebaskan dirinya dari segala bentuk dominasi yang memiskinkan dan membodohkan.

Tugas utama fasilitator pemberdayaan masyarakat adalah mengembangkan pembelajaran bagi masyarakat lokal untuk membangun tingkat kemandirian dalam menyelesaikan masalah yang mereka hadapi. Bersamaan dengan itu, membangun kesadaran kritis masyarakat terhadap berbagai format ekonomi-politik yang berlangsung 
secara mapan dibarengi dengan memperkuat kemampuan masyarakat untuk berdialog sehingga mempunyai kapasiatas transaksional dan diharapkan bisa mengambil posisi tawar yang kuat dengan kekuatan lain. Upaya-upaya itu harus disertai dengan menggalang kemampuan untuk membentuk aliansi dengan kekuatan-kekuatan lain agar mampu mempengaruhi perubahanperubahan kebijakan yang lebih menguntungkan bagi kehidupan mereka.

Berdasar uraian tersebut, maka upaya pemberdayaan masyarakat haruslah melibatkan beberapa pendekatan dan strategi sebagai berikut: a. Memulai dengan tindakan mikro.

Proses pembelajaran rakyat harus dimulai dengan tindakan mikro, namun memiliki konteks makro dan global. Dialog mikro makro harus terus menerus menjadi bagian pembelajaran masyarakat agar berbagai pengalaman mikro dapat menjadi policy input dan policy reform sebagai unsur utama pemberdayaan sehingga memiliki dampak yang lebih luas.

b. Membangun kembali kelembagaan rakyat.

Peran serta masyarakat menjadi keniscayaan bagi semua upaya pemberdayaan masyarakat. Peran serta masyarakat secara teknis membutuhkan munculnya kelembagaan sosial, ekonomi dan budaya yang benar-benar diciptakan oleh masyarakat sendiri.

c. Pengembangan kesadaran rakyat.

Karena peristiwa ekonomi juga merupakan peristiwa politik atau lebih dikenal politik ekonomi, maka tindakan yang hanya berorientasi memberikan bantuan teknis jelas tidak memadai. Yang diperlukan adalah tindakan politik yang berbasis pada kesadaran rakyat untuk membebaskan diri dari belenggu kekuatan-kekuatan ekonomi dan politik yang menghambat proses demokratisasi ekonomi. Pendidikan alternatif dan kritis merupakan pendekatan yang sangat penting sebagai upaya membangun kesadaran rakyat.

d. Redistribusi sumberdaya ekonomi merupakan syarat pemberdayaan rakyat.

Redistribusi aset bukanlah sejenis hibah. Tapi merupakan keikutsertaan dalam pengambilan keputusan dalam pengelolaan sumberdaya ekonomi nasional serta 
pendayagunaannya dengan segala resiko dan keuntungan yang akan dihadapi.

e. Menerapkan model pembangunan berkelanjutan.

Sudah tidak jamannya lagi mempertentangkan pendekatan ekonomi dan lingkungan. Memperpanjang perdebatan masalah ini akan memperpanjang deretan kerusakan sumber daya lingkungan yang mengancam terhadap proses pembangunan itu sendiri. Yang harus diwujudkan adalah setiap peristiwa pembangunan harus mampu secara terus menerus mengkonservasi daya dukung lingkungan. Dengan demikian daya dukung lingkungan akan dapat dipertahankan untuk mendukung pembangunan.

f. Kontrol kebijakan dan advokasi.

Upaya menciptakan sistem ekonomi modern dan meninggalkan sistem ekonomi primitif (primitive capitalisme) haruslah didukung oleh berbagai kebijakan politik yang memadai oleh pemerintah. Agar kebijakan pemerintah benar-benar mendukung terhadap upaya pemberdayaan rakyat maka kekuasaan pemerintah harus dikontrol. Setiap kebijakan yang bertentangan dengan upaya pemberdayaan rakyat haruslah diadvokasi. Untuk ini sangatlah penting munculnya kelompok penekan yang melakukan peran kontrol terhadap kebijakan.

g. Pengembangan sektor ekonomi strategis sesuai dengan kondisi lokal (daerah).

Ini merupakan upaya untuk menggaet gerbong ekonomi agar ekonomi rakyat kembali bergerak. Yang dimaksud produk strategis (unggulan) di sini tidak hanya produksi yang ada di masyarakat laku di pasaran, serta memiliki keterkaitan sosial yang tinggi.

h. Mengganti pendekatan kewilayahan administratif dengan pendekatan kawasan.

Pemberdayaan masyarakat tidak mungkin didasarkan atas kewilayahan administratif. Pendekatan kewilayahan administratif adalah pendekatan birokrasi/kekuasaan. Pendekatan kawasan berarti lebih menekankan pada kesamaan dan perbedaan potensi yang dimiliki oleh suatu kawasan tertentu. Dengan pendekatan ini akan memungkinkan terjadinya pemberdayaan masyarakat 
dalam skala besar disamping keragaman model yang didasarkan atas keunggulan antara kawasan satu dengan lainnya. Lebih lanjut akan memungkinkan terjadinya kerjasama antar kawasan yang lebih produktif.

i. Mengembangkan penguasaan pengetahuan teknis.

Perlu dipahami bersama bahwa desakan modernisasi telah menggusur ilmu pengetahuan dan teknologi lokal dan menciptakan ketergantungan rakyat pada input luar serta hilangnya kepercayaan diri yang sangat serius. Pendidikan alternatif yang mampu mengembalikan kepercayaan diri rakyat serta dapat menggerakkan proses pengembangan ilmu pengetahuan dan teknologi yang benar-benar sesuai dengan kebutuhan mereka sangat penting untuk dikembangkan.

j. Membangun jaringan ekonomi strategis.

Jaringan ekonomi stategis akan berfungsi untuk mengembangkan kerjasama dalam mengatasi keterbatasan-keterbatasan yang dimiliki kelompok ekonomi satu dengan lainnya baik dalam bidang produksi, pemasaran, teknologi dan permodalan. Disamping itu jaringan strategis juga akan berfungsi sebagai media pembelajaran rakyat dalam berbagai aspek dan advokasi.

Cook dan Macaulay memberikan definisi pemberdayaan sebagai “ alat penting untuk memperbaiki kinerja organisasi melalui penyebaran pembuatan keputusan dan tanggungjawab”. Dengan demikian, akan mendorong keterlibatan para pengurus maupun santri dalam pengambilan keputusan dan tanggungjawab. Dengan demikian dalam pesantren, pemberdayaan diarahkan pada pembina, pengurus, anggota maupun masyarakat sekitar dan lembaga maupun komponen yang terlibat. Misalnya dalam kegiatankegiatan tertentu, tanggungjawab dilimpahkan kepada para anggota yang mampu (santri) dan ternyata hasilnya jauh lebih baik dibanding seandainya kegiatan tersebut ditangani langsung oleh pimpinan utama/tokoh agama sendiri. Dengan kebijakan itu, pengambilan keputusan maupun tugas terdistribusi pada seluruh pengurus dan anggota sehingga hal-hal penting yang membutuhkan keputusan dan tindakan cepat tidak harus menunggu keputusan dari pimpinan (kyai/tokoh agama 
sentral dsb).

$$
\text { Dalam pengembangan }
$$

masyarakat muslim khususnya, pemberdayaan merupakan cara yang sangat strategis dan praktis sekaligus produktif untuk mendapatkan hasil yang jauh lebih baik dari berbagai program pembangunan dan pengembangan masyarakat secara luas. Proses yang ditempuh untuk mendapatkan hasil yang terbaik dan produktif tersebut adalah dengan membagi tanggung jawab secara proporsional kepada pengurus dan santri. Pada dasarnya pemberdayaan terjadi melalui beberapa tahap. Pertama, masyarakat mengembangkan sebuah kesadaran awal bahwa mereka dapat melakukan tindakan untuk meningkatkan kehidupannya dan memperoleh seperangkat keterampilan agar mampu bekerja lebih baik. Melalui upaya tersebut, pada tahap kedua, mereka akan mengalami pengurangan perasaan ketidak-mampuan dan mengalami peningkatan kepercayaan diri. Akhirnya, ketiga, seiring dengan tumbuhnya keterampilan dan kepercayaan diri, masyarakat bekerja sama untuk berlatih lebih banyak mengambil keputusan dan memilih sumber-sumber daya yang akan berdampak pada kesejahteraan mereka.

\section{Strategi Pengelolaan Lahan Kritis}

Akhir-akhir ini ada pendapat yang menyatakan bahwa strategi swasembada pangan perlu diubah menjadi swadaya pangan. Artinya, yang harus diutamakan bukan meningkatkan produksi tetapi bagaimana menumbuhkan kemampuan membeli bahan pangan. Dalam kondisi yang tidak menguntungkan, impor pangan tertentu merupakan alternatif yang dianggap baik.

Apapun strategi yang dianut, pengelolaan usaha tani tanaman pangan tetap perlu dilaksanakan sebaik mungkin dengan tujuan produksi tinggi dan berwawasan lingkungan agar kebutuhan pangan nasional tidak tergantung kepada negara lain. Dalam kaitan itu, penelitian dan pengembangan teknologi usaha tani perlu ditingkatkan, termasuk penelusuran perluasan areal baru, baik oleh pengambil kebijakan maupun para ahli dan pihak terkait lainnya.

Sistem usaha tani konservasi adalah penataan usaha tani yang stabil berdasarkan daya dukung lahan yang didasarkan atas tanggapannya terhadap faktor-faktor fisik, biologis dan sosial 
ekonomis serta berlandaskan sasaran dan tujuan rumah tangga petani dengan mempertimbangkan sumber daya yang tersedia (UACP-FSR 1990).

Penanganan masalah secara parsial yang telah ditempuh selama ini ternyata tidak mampu mengatasi masalah yang kompleks dan juga tidak efisien ditinjau dari segi biaya. Banyak teknologi yang dianjurkan untuk menekan erosi tanah, seperti pembuatan teras dan galengan. Akan tetapi, petani pada umumnya tidak memiliki cukup biaya untuk pembuatan teras. Oleh karena itu, belakangan ini telah dianjurkan pula sistem usaha tani konservasi. Pendekatan parsial untuk mengatasi masalah produktivitas tanaman adalah ciri suatu penelitian yang berbasis komoditas. CGIAR (Consultative Group on International Agriculture Research) mengubah strategi penelitian melalui pendekatan holistik dengan fokus sumberdaya. Dalam skala makro strateginya disebut ecoregional initiative dan dalam skala mikro dijabarkan dalam integrated crop management (Kartaatmadja dan Fagi, 1999).

Kunci keberhasilan budidaya tanaman pangan berkelanjutan (Effendi et al, 1986) antara lain : a. Mengusahakan agar tanah tertutup tanaman sepanjang tahun guna melindungi tanah dari erosi dan pencucian

b. Mengembalikan sisa-sisa tanaman, kompos dan pupuk kandang ke dalam tanah guna memperbaiki/mempertahankan bahan organik tanah.

Sedangkan kebiasaan petani dalam mengusahakan tanaman pangan sebagian besar limbah pertaniannya diangkut keluar untuk pakan dan kayu bakar, dibakar pada saat persiapan tanah atau terbawa erosi, oleh karena itu makin lama kandungan bahan organik tanah makin menurun dan diikuti oleh peningkatan erosi tanah karena kurangnya tindakan konservasi tanah.

Pengusahaan budidaya tanaman yang dapat menutup permukaan tanah sepanjang tahun merupakan tindakan konservasi vegetatif yang baik. Tindakan tersebut akan lebih baik lagi jika sisa tanaman juga dikembalikan sebagai tambahan bahan organik tanah. Bahan organik yang tinggi tidak hanya akan menambah nutrisi tanah setelah melapuk, tetapi juga dapat berperan sebagai penyanggah dari pupuk yang diberikan, mengikat air lebih baik dan meningkatkan daya infiltrasi tanah dari 
curah hujan yang jatuh akhirnya dapat mengurangi erosi dan aliran permukaan serta dapat meningkat produksi dan pendapatan petani. Penelitian jangka panjang penggunaan bahan organik pada pola tanam tanaman pangan di lahan kering di laboratorium lapangan ungaran. Hasil penelitian selama 3 tahun menunjukkan bahwa pemberian pupuk kandang cukup satu kali saja pada awal musim hujan, karena tidak ada perbedaan yang berarti antara yang diberikan tiga kali dan satu kali. Hasil pertanaman jagung dan ubi kayu lebih tinggi pada pola tanam yang didahului oleh tanaman kacang tanah dibanding yang didahului oleh padi googo, masing-masing meningkat 29 dan $50 \%$ (Toha dan Abdurrahman, 1991).

Berdasarkan kaidah konservasi tanah dan air, lahan yang berkemiringan $15 \%$ tidak dibenarkan untuk usaha tani tanaman pangan (semusim). Akan tetapi, karena tidak punya pilihan lain maka petani menggunakan lahan tersebut unutk usaha tani tanaman semusim. Sehubungan dengan itu, Hakim et al., (1991) berpendapat bahwa usaha tani tanaman pangan pada lahan tersebut dapat dianjurkan, tetapi perlu diikuti dengan upaya konservasi tanah dan air. Dari laporan Hakim et al.,
(1991) diketahui bahwa tanaman jagung, kedelai dan kacang hijau dapat berproduksi dengan baik pada lahan kritis yang sudah dikonservasi.

Upaya dalam mempertahankan atau meningkatkan produktivitas lahan kritis hendaknya didekati dengan menerapkan sistem usaha tani konservasi melalui pengaturan pola tanam, penambahan bahan organik dengan daur ulang sisa panen dan gulma, serta penerapan budidaya lorong (Adiningsih dan Mulyadi, 1992). Penerapan teknologi tersebut akan memberikan pengaruh positif terhadap produktivitas tanah seperti meningkatnya ketersediaan P dan bahan organik tanah serta menurunnya kadar Al.

\section{TUJUAN PENELITIAN}

Berdasarkan hasil diskusi peneliti dan penggalian informasi dari masyarakat maka tujuan dari penelitian ini adalah :

1. Mengetahui keadaan kekritisan lahan hutan di Desa Bulukerto.

2. Pengoptimalan penerapan sistem penanaman lorong pada lahan yang mempunyai tingkat kemiringan tinggi tinggi $\left(>45^{\circ}\right)$. 
3. Sosialisasi jenis tanaman dan pola tanam pada lahan yang mempunyai kemiringan tinggi $\left(>45^{0}\right)$ yang mempunyai nilai ekonomi tinggi dan berwawasan lingkungan.

4. Memberikan penyuluhan dan meningkatkan kesadaran masyarakat dalam menjaga dan melestarikan lingkungannya khususnya hutan disekitarnya.

\section{METODE PENELITIAN}

Metode dan teknik yang digunakan dalam kegiatan ini menggunakan pendekatan participatory. Masyarakat (LMDH) dijadikan sebagai narasumber. Pendekatan yang dilakukan adalah baik melalui individual meeting, focus discussion group (FGD), wawancara dan lainnya. Hasilnya kemudian di cross-checkkan antara jawaban masyarakat dan kemudian diklarifikasikan ke perangkat desa.

Dari metode ini kemudian diturunkan ke dalam teknik penelitian sebagai berikut :

\section{Pemetaan (Mapping)}

Teknik ini bertujuan untuk memfasilitasi masyarakat dalam mengungkapkan keadaan wilayah desanya sendiri. Pemetaan adalah menggambarkan kondisi wilayah lahan, peruntukan lahan, pemukiman masyarakat termasuk masalah sosial yang ada dimasyarakat. Dalam penelitian ini masyarakat yang dijadikan obyek penelitian adalah petani hutan dan lembaga masyarakat desa hutan (LMDH).

\section{Transek}

Transek merupakan teknik untuk memfasilitasi masyarakat dalam pengamatan langsung kondisi lahan garapannya dan keadaan sumber daya alam dengan cara berjalan menelusuri wilayah hutan dengan mengikuti suatu lintasan tertentu yang disepakati. Dengan teknik transek ini diperoleh gambaran keadaan lahan hutan garapan petani beserta masalah-masalah, perubahan keadaan yang diinginkan dan potensi-potensinya.

\section{Diagram Venn}

Teknik ini digunakan untuk melihat hubungan masyarakat dengan berbagai lembaga yang terdapat di Desa Bulukerto dan lingkungan sekitarnya. Diagram venn memfasilitasi diskusi masyarakat untuk mengidentifikasi pihak-pihak apa saja yang ada di desa tersebut, serta menganalisa dan mengkaji 
perannya, kepentingannya untuk masyarakat dan manfaat untuk masyarakat.

\section{Bagan Perubahan dan}

\section{Kecenderungan}

Teknik ini memfasilitasi masyarakat dalam mengenali perubahan dan kecenderungan berbagai keadaan, kejadian serta kegiatan masyarakat dari waktu ke waktu. Dari besarnya perubahan hal-hal yang diamati dapat diperoleh gambaran adanya kecerderungan umum perubahan yang diharapkan masyarakat yang terkait dengan pengelolaan lahan kritis di masa mendatang.

\section{Livelihood Analysis}

Teknik ini adalah alat analisis mata pencaharian LMDH. Masyarakat akan terpandu untuk mendiskusikan kehidupan mereka dari aspek mata pencaharian. Tujuan teknik ini adalah memfasilitasi pengenalan dan analisa terhadap jenis pekerjaan.

\section{TEMUAN PENELITIAN DAN PEMBAHASAN}

Sosialisasi program penanganan lahan kritis ini bertujuan untuk meningkatkan kesadaran masyarakat desa Bulukerto dalam memanfaatkan potensi wilayahnya yang belum disesuaikan dengan kondisi dan tata guna lahan yang benar, sehingga aspirasi dan peran serta langsung dari masyarakat (berbasis masyarakat) dapat tertampung dan menghasilkan rumusan sebagai landasan dalam pengelolaan sumber daya alam secara benar dan berwawasan lingkungan. Selain itu sosialisasi ini juga ditunjukan pembuktian-pembuktian pada masyarakat tentang manfaat pengelolaan lahan yang disesuaikan dengan tata guna lahan. Selain itu untuk memperjelas rencana program penelitian juga disertai demo plot penanganan lahan (contoh-contoh model teraserting). Hal ini diharapkan masyarakat akan lebih memahami dan menyadari bahwa cara dan kebiasaan sistem pertanian yang mereka lakukan sudah tidak sejalan dengan konsep pelestarian lingkungan. Jika sistem itu mereka teruskan lambat laun secara ekonomi masyarakat desa Bulukerto juga akan mengalamai kerugian yang besar dan secara ekologi akan menyebabkan terjadinya bencana alam.

Berdasarkan hasil penggalian informasi masyarakat oleh tim peneliti bersama aparat desa termasuk dari 
kepala desa, sekretaris desa dan dalam analisis pohon masalah sebagai pengurus desa maka dapat dituangkan berikut :



Gambar 1. Analisis pohon masalah pengelolaan lahan hutan Desa Bulukerto.

Berdasarkan pohon masalah dimana yang menjadi masalah pokok adalah belum optimalnya pengelolaan lahan hutan, maka analisis pohon harapannya adalah sebagai berikut:

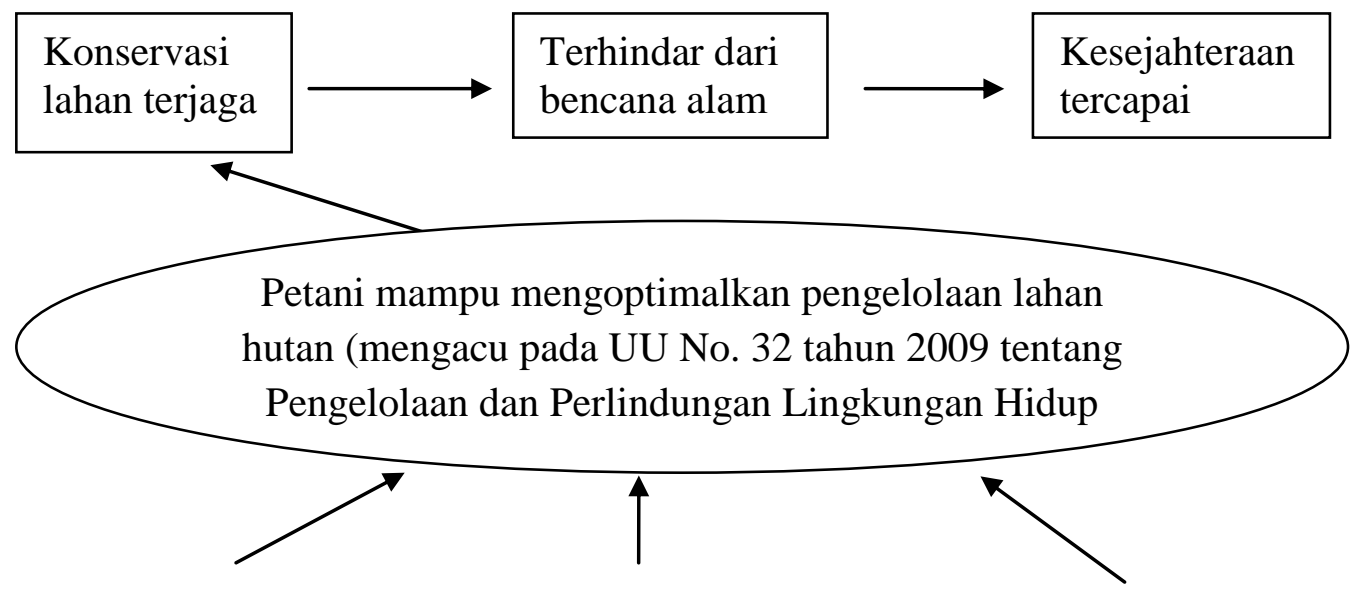




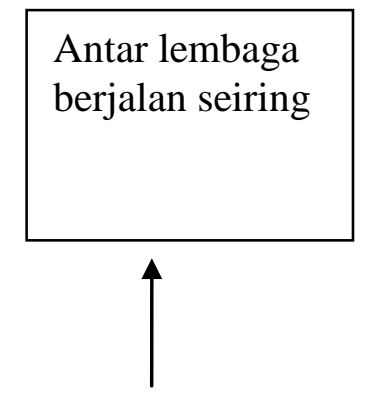

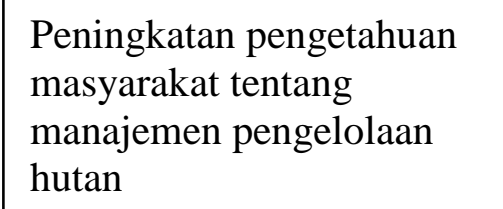

hutan

\section{Aparat berpihak pada masyarakat}

Pemahaman petani meningkat (dalam sistem pertaniannya)

Gambar 2. Analisis pohon harapan pengelolaan lahan hutan Desa Bulukerto.

Dari berbagai permasalahan tentang pengelolaan lahan hutan di Desa Bulukerto maka perlu dibuat matrik penyelesaian masalah berdasarkan skala prioritas masalah mana yang akan ditangani terlebih dahulu. Analisis papan penyelesaian masalah adalah sebagai berikut :

Tabel 1. Analisis papan catur matrik prioritas penyelesaian masalah

\begin{tabular}{|l|l|c|c|c|c|c|}
\hline No & Masalah & Urgensi & Relevansi & SDM & $\begin{array}{l}\text { Kekuatan } \\
\text { Tim }\end{array}$ & Skor \\
\hline 1 & $\begin{array}{l}\text { Kurang koordinasi antar } \\
\text { lembaga \& masyarakat dlm } \\
\text { pengelolaan hutan }\end{array}$ & 5 & 5 & 3 & 17 \\
\hline 2 & $\begin{array}{l}\text { Jenis tanaman masih sayuran } \\
\text { semusim }\end{array}$ & 3 & 4 & 4 & 4 & 15 \\
\hline 3 & $\begin{array}{l}\text { Lahan mempunyai } \\
\text { kemiringan tinggi }\end{array}$ & 5 & 5 & 3 & 3 & 16 \\
\hline 4 & Manajemen pertanian rendah & 4 & 4 & 3 & 3 & 14 \\
\hline 5 & Wawasan lingkungan rendah & 4 & 3 & 3 & 3 & 13 \\
\hline
\end{tabular}

1. Koordinasi dan penyamaan persepsi

Setelah matriks prioritas penyelesaian masalah dibuat, selanjutnya direncanakan jenis-jenis kegiatan yang sebelumnya telah dibicarakan bersama dengan masyarakat dengan memperhitungkan SDM dan sarana prasarana yang ada. Dengan skala prioritas adalah sebagai berikut : antara petani dan pihak-pihak terkait dalam pengelolaan hutan.

2. Sosialisasi jenis-jenis tanaman yang sesuai dengan tingkat kemiringan lahan yang berwawasan lingkungan dan mempunyai nilai ekonomi tinggi.

3. Pelatihan penataan lahan yang menyesuaikan kondisi kemiringan lahan. 
4. Pelatihan manajemen petani dalam mengoptimalkan pengelolaan lahan garapannya yang berwawasan lingkungan dan bernilai ekonomi tinggi.

5. Sosialisasi UU No. 32 tahun 2009 tentang pengelolaan dan perlindungan lingkungan hidup .

Skala rencana prioritas penyelesaian masalah ini selanjutnya didiskusikan oleh peneliti bersama masyarakat untuk melakukan analisis kelayakan strategis terhadap suatu program. Apakah suatu program mempunyai kelayakan untuk dilakukan atau tidak, apakah program tersebut disukai dan disambut baik oleh masyarakat atau tidak dan lainlain. Apabila suatu program tidak didukung oleh masyarakat maka percuma saja kegiatan tersebut dilakukan. Selain itu peneliti dan masyarakat juga harus mempertimbangkan waktu, dana, fasilitas serta SDM yang tersedia baik dari masyarakat, tim peneliti UIN malang maupun lembaga lain yang dapat membantu dalam penyelesaian program tersebut. Dukungan secara politis maupun administratif dari berbagai pihak khusus aparat pemerintahan pada kegiatan ini juga harus diketahui sejak dini.

Dalam pelaksanaan penelitian PAR ini, terlihat adanya dukungan yang kuat dari masyarakat/petani. Hal ini ditandai dengan adanya perubahan masyarakat yang secara signifikan dalam pengoptimalan peran lembaga masyarakat desa hutan (LMDH) dalam pengelolaan hutan (lahan kritis) di Desa Bulukerto Kecamatan Bumiaji Kota Batu. Adapun perubahan itu adalah tumbuhnya pengetahuan, wawasan, kesadaran masyarakat dalam pengelolaan lahan dengan tingkat kemiringan > $45^{\circ}$ menjadi lahan produktif dan berwawasan konservasi sumber daya alam (SDA). Selain itu tumbuhnya upaya-upaya masyarakat untuk ikut serta dan berperan langsung dalam menjaga dan melestarikan SDA yang ada di wilayahnya

Salah satu indikator keberhasilan program ini adalah adanya keinginan yang kuat dari petani (LMDH) akan keberlanjutan penelitian ini di tahun depan, sehingga kegiatan tersebut mempunyai manfaat terus karena dimungkinkan adanya sebuah kegiatan baru yang merupakan keberlanjutan dari kegiatan sebelumnya. 
Selain itu dari kegiatan PAR ini diharapkan masyarakat dampingan dapat menjadi pilot proyek/model percontohan bagi desa lain terutama yang mempunyai permasalahan tentang penanganan lahan kritis.

\section{KESIMPULAN DAN SARAN}

Berdasarkan hasil kegiatan pada program pemberdayaan (PAR) tahun pertama 2009 terdapat tiga permasalahan lingkungan mendasar khususnya di wilayah DAS Brantas Hulu, yaitu :

1. Kerusakan hutan

Kondisi lahan di Desa Bulukerto saat ini berada pada tahap mendekati kritis, sebagian besar lahan ditanami pohon pinus. Akan tetapi sebagian besar dari pohon pinus tersebut banyak yang tumbang.

2. Ancaman kerusakan lahan

Belum adanya manajemen pengelolaan lahan yang benar yang mengacu pada UU No. 32 tahun 2009 tentang pengelolaan dan perlindungan lingkungan hidup.

3. Ancaman kematian sumber air

Dari 250 sumber air yang ada 111 sumber air telah mati/kering. Perlu kita ketahui bahwa $80 \%$ suplay pengairan dan kebutuhan air di Jawa Timur diambil dari sumber air di Kota Batu.

Dari ketiga permasalahan tersebut pada program pemberdayaan (PAR) tahun pertama 2009 ini tim peneliti memfokuskan pada penanganan ancaman kerusakan hutan dan lahan di Desa Bulukerto. Berdasarkan hasil program PAR pada tahun pertama ini (2009), maka dapat direkomendasikan hal-hal sebagai berikut :

1. Perlu adanya keselarasan dan kerjasama yang baik (sinergisme) antara pemerintah daerah, Perguruan tinggi, LSM dan masyarakat dalam mengelola dan menangani permasalahan lahan kritis ini. Jika semua pihak bisa menyatukan persepsi maka permasalahan ini akan bisa diatasi.

2. Pemerintah harus mulai mendengarkan aspirasi masyarakat dalam pengambilan kebijakannya. Masyarakat diajak berdialog secara langsung mulai dari perencanaan, perumusan, pelaksanaan dan pemungutan manfaat dari setiap kebijakan yang akan dikeluarkan. Dengan partisipasi langsung ini memungkinkan masyarakat dapat menghitung secara langsung 
dampak secara ekonomi dan ekologi dari setiap keputusan yang akan diambilnya. Aspek ekonomi dan konservasi yang sinergi merupakan dua aspek yang tidak dapat dipisahkan karena mempunyai peranan yang penting dalam melakukan kajian pengelolaan SDA.

3. Peran pemerintah harus lebih dioptimalkan khususnya dalam pembuatan Perda yang mengatur tentang pengelolaan dan perlindungan lingkungan hidup.

4. Perlu adanya kesadaran yang tinggi pada masyarakat dalam menjaga dan melestarikan lingkungannya khususnya hutan disekitarnya.

\section{DAFTAR PUSTAKA}

Abdullah, Taufik (ed). 1979. Agama, Etos Kerja dan Perkembangan Ekonomi. LP3ES, Jakarta.

Adjid, D.A. 1993. Kebijaksanaan Swasembada dan Ketahanan Pangan. Proseding Simposium Penelitian Tanaman Pangan III. Jakarat/Bogor 23-25 Agustus 1993. p50-64.

Asdak, C. 2002. Hidrologi dan Pengelolaan Daerah Aliran Sungai. Gajah Mada University Press. Yogyakarta.
Balai KSDA Jawa Timur. 2006. Data Statistik Balai KSDA Jawa Timur, Departemen Kehutanan. Jakarta.

Blaikie, Norman. 2000. Designing Sosial Research. First Published in 2000 by Polity Press in association with Blackwell Publishers Ltd.

Britha Mikkelsen. 1999. Metode Penelitian Partisipatoris dan Upaya-upaya Pemberdayaan. Yayasan Obor Indonesia, Jakarta.

Cook and Macaulay, 1997. Perfect Empowerment (Terjemahan). Gramedia Pustaka, Jakarta.

E. Mulyasa. 2003. Manajemen Berbasis Sekolah Konsep, Strategi dan Implementasi. PT. Remaja Rosdakarya, Bandung.

Joyosuharto, S. 1985. Dasar-Dasar Pemikiran Klasifikasi Bentuk Lahan. Fakultas

Geografi, UGM. Yogyakarta.

Hakim, N. 1985. Pengaruh Sisa Pupuk Hijau, Kapur, pupuk $P$ dan Mg pada Tanah Podsolik Terhadap Produksi Jagung. Makalah Seminar Hasil Penelitian Perguruan Tinggi. Bandung, 2528 Februari 1985. Ditjen Dikti Depdikbud.

Lillesand, TM dan Kiefer. 1990. Remote Sensing and Image Interpretation, Gajah Mada University Press, Yogjakarta. 
Lilik Kurniawan, Iwan G Tejakusuma, Heru Sri Naryanto, Suryana Prawiradisastra. 2007. Rapid Assessment Bencana Indonesia 2007. Pusat Teknologi Sumberdaya Lahan, Wilayah dan Mitigasi Bencana, TPSA, BPPT, Jakarta.

Lopulisa. 1995. Penggunaa Llahan dalam Perspektif Pembangunan berkelanjutan di Indonesia. Kongres VI HITI, Serpong, Jakarta 12-15 Desember 1995.

Murtiono, U.H. 2001. Pedoman Teknis Pengukuran dan Perhitungan Parameter Morfometri DAS. Jurnal Info DAS, nomor 10 tahun 2001. Badan Penelitian dan Pengembangan Kehutanan, BTP DAS Surakarta.

Reason, Peter and Bradbury, Hilary. 2002. Handbook of Action Research Participative Inquiry and Practice. Sage Publications Ltd 6 Bunhill Street London EC2A4PU, London.

Strauss, Anselm and Corbin, Yuliet. 2003. Dasar-Dasar Penelitian Kualitatif, Tata Langkah dan Teknik-Teknik Teorisasi Data. Pustaka Pelajar, Yogyakarta.
Toha H.M. dan Abdurrahman, A. 1991. Penggunaan bahan organik pada pola tanam lahan kering di tanah vulkanik eutropept laboratotoirum lapangan uangaran, semarang. Proyek Penelitian Penyelamatan Hutan, Tanah dan Air. Badan Penelitian dan Pengembangan Pertanian. Departemen Pertanian. 1991.

Turner, S, Bryan. 1984. Weber and Islam. Diterjemahkan oleh G.A. Ticoalu, Sosiologi Islam Suatu Telaah Analisis Atas Tesa Sosiologi Weber. PT. Rajawali Grafindo Persada, Jakarta.

Umi Haryati., A Rachman., Y. Soelaeman dan T. Prasetyp. 1991. Efectivitas Penurunan Erosi, Hasil Tanaman Pangan dan Daya Dukung Ternak dalam Sistem Pertanaman Lorong. Pembahasan Hasil Penelitisn UACP-FSR. Bandung.

UNDP. 1999. NGO Perspectives on Poverty, Environment and Development. UNDP, New York. 